\title{
From divide to nexus : Interconnected land use and water governance changes shaping risks related to water
}

\section{Räsänen, Aleksi}

2018-01

Räsänen , A , Nygren , A , Monge Monge , A A , Käkönen , M , Kanninen , M \& Juhola , S 2018 , ' From divide to nexus : Interconnected land use and water governance changes shaping risks related to water ' , Applied Geography , vol. 90 , pp. 106-114 . https://doi.org/10.1016/j.apgeog.2017.1

http://hdl.handle.net/10138/308823

https://doi.org/10.1016/j.apgeog.2017.11.005

acceptedVersion

Downloaded from Helda, University of Helsinki institutional repository.

This is an electronic reprint of the original article.

This reprint may differ from the original in pagination and typographic detail.

Please cite the original version. 


\section{From divide to nexus: Interconnected land use and water governance}

\section{changes shaping risks related to water}

Aleksi Räsänen $^{\text {ad* }}$, Anja Nygren ${ }^{\mathrm{b}}$, Adrián Monge Monge ${ }^{\mathrm{c}}$, Mira Käkönen ${ }^{\mathrm{b}}$, Markku Kanninen ${ }^{\mathrm{c}}$ \& Sirkku Juhola $^{\text {ae }}$

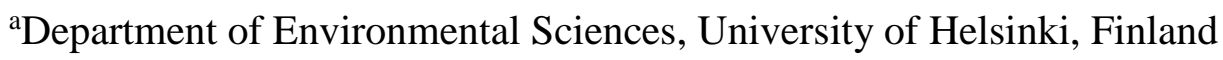

${ }^{\mathrm{b}}$ Development Studies, Department of Political and Economic Studies, University of Helsinki, Finland

${ }^{c}$ Viikki Tropical Resources Institute, Department of Forest Sciences, University of Helsinki, Finland

${ }^{\mathrm{d}}$ Department of Geography, Norwegian University of Science and Technology, Norway

e Department of Built Environment, Aalto University, Finland

*Corresponding author, aleksi.rasanen@ helsinki.fi, +358504489001, Department of Environmental

Sciences, P.O. Box 65, FI-00014 University of Helsinki, Finland 


\section{Abstract}

Land use changes have been recognized to have considerable impacts on water; and vice versa, changes in water use and governance may have implications on land use and governance. This study analyzes recent land use/land cover (LULC) changes, and how changes in land use and water governance are perceived to affect land use and water-related risks in three case-study areas exposed to frequent flooding and inadequate or deteriorating water quality. The areas studied included the Vantaa basin in Finland, a section of the Grijalva basin in Mexico, and the Lower Xe Bang Fai basin in Laos. We show how there are complex and context-specific interrelationships between land use, water governance, and waterrelated risks in each study area. In a remote sensing analysis of LULC changes during the past 30 years, we found that LULC changes have been the most dramatic in Xe Bang Fai, Laos in the form of expanding agriculture and built-up areas; however, there has also been an expansion of built-up areas in the two other sites. According to our stakeholder scenario workshop data, analysis of policy documents and field visits, the nexus between land, water and risks is recognized to some extent in each study area. There have been modest shifts toward more integrated land use and water governance in Vantaa and Grijalva, while the integrated governance seems to have been most absent in Xe Bang Fai. Tighter integration of land and water policies is needed in all the three cases to manage the land use changes in a way that their effects on water-related risks will be minimized.

Keywords: land use; satellite imagery; risk; vulnerability; water management; water governance 


\section{Introduction}

Water-related problems (e.g. floods, droughts and poor water quality), and vulnerability towards them, are driven by changes in land and water use, as well as by their interconnections. Unsustainable land use changes have been recognized to have considerable implications on water (Delpla et al. 2009; Foley et al. 2005; Rockström et al. 2009; Steffen et al. 2015), while changes on water use and governance have considerable effects not only on water but also on land use (Alemayehu et al. 2009; Wang et al. 2016). In addition, land and water use changes may significantly increase vulnerability to water-related hazards, such as adverse floods (Lioubimtseva and Henebry 2009; McCubbin et al. 2015).

Land use changes and water-related risks and vulnerabilities are driven by several factors that include local processes and global political-economic forces (Lambin et al. 2001; Meyfroidt et al. 2013). Despite universal trends, such as agricultural intensification and expansion of industrial activities and urban settlements (Meyfroidt et al. 2013), the combination of exact drivers of change, their intensities and linkages with water-related risks and vulnerability are contextual and have specific outcomes and meanings in particular sites (Güneralp et al. 2015; Lambin et al. 2001; Rockström et al. 2014). Thus, it is important to understand the similarities and differences in socio-spatial contexts regarding the implications of the land use and water governance changes on water-related risks and vulnerability (PahlWostl 2015).

By using a mixed-methods approach, we evaluated linkages between changes related to land and water and associated water-related risks and vulnerability in three case studies located in Finland, Mexico and Laos. We quantified land use/land cover (LULC) changes during the past 30 years with the help of Landsat remote sensing data and supervised classification and evaluated (1) to what effect changes in land and water use can be tracked using remote sensing. Furthermore, with the help of qualitative data gathered from stakeholder scenario workshops, policy documents, field visits and interviews, we asked 
what are the institutional perceptions on (2) how changes in land use and governance have affected waterrelated changes and risks during the past 30 years and how they will affect water during the following 30 years, and (3) how changes in water use and governance have affected and will affect land use and its governance.

\section{Water-related risks and their connection to the use and governance of land and water}

In the centerpiece of our analysis are water-related risks and vulnerability (Fig. 1). In line with the IPCC (2014), we distinguish risks from vulnerability with the former referring to potential consequences of water-related problems, such as floods, droughts and low water quality, and the latter referring to preexisting condition of individuals, communities and societies in terms of how heavily they will be affected by water-related problems. For instance, major disparities in social vulnerability often indicate that increasing flood risks and worsening conditions of water quality are socially differentiated (Nygren 2016; Sze et al. 2009). 


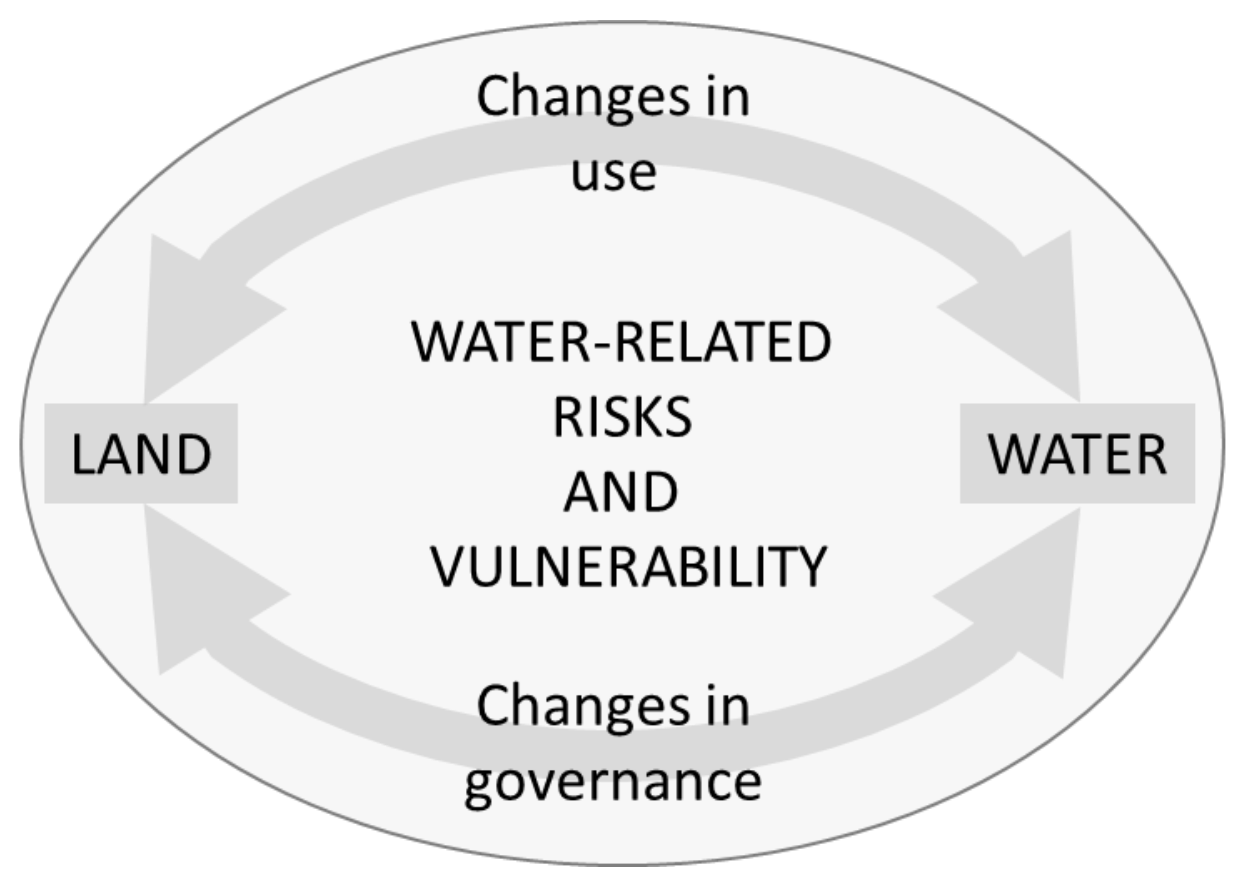

Figure 1. Analytical framework of the study.

Water-related risks and vulnerability are influenced by changes in land and water use, as well as their governance. Furthermore, processes related to land and water are in a bidirectional relationship (Fig. 1), and this interaction has implications for risks. We differentiate land and water use from land and water governance. The former refers to how and where land and water resources are utilized. Governance, on the other hand, refers to the regulation of development and management of land and water resources (c.f. Pahl-Wostl 2015).

Changes in land use affect both the exposure to flooding (de Moel et al. 2011; Güneralp et al. 2015; Liu et al. 2014; Sze et al. 2009) and flooding patterns by changing the water-flow regimes and runoff generation (Alexakis et al. 2014; Sze et al. 2009; Zhou et al. 2013). In addition to flooding, changes in land use may modify the availability of water, which may have implications e.g. for communities, agricultural livelihoods and energy production (Rahman et al. 2015; Tong et al. 2012; Zhang et al. 2017). Furthermore, land use changes and increasing human activities have also significant impacts on water quality patterns (Foley et al. 2005; Liu et al. 2015; Rockström et al. 2014; Tu 2011; Wilson 2015). 
Large-scale water management infrastructure and hydropower projects significantly alter hydrological systems (e.g. streamflow, runoff, storage and infiltration) (Gao et al. 2013; Lu et al. 2014; Muñoz-Salinas and Castillo 2015), and changes in management and governance of water resources have also implications for land use (Alemayehu et al. 2009; Desta et al. 2017; Wang et al. 2016). In many cases, changes in land and water use are clearly intertwined, such as in the embankment and canalization of water for flood protection and to support land conversion to agriculture and built-up areas (Marçal et al. 2017; Ritzema and Van Loon-Steensma 2017). Due to the interconnectedness of land and water, there have been calls for and analyses of the land-water-nexus and integrated land and water management (Benson and Lorenzoni 2017; Borchardt et al. 2016; Chen et al. 2018; Ringler et al. 2013; Ritzema and Van Loon-Steensma 2017; Rockström et al. 2014).

LULC changes have been tracked for decades using remote sensing methods (Singh 1989; Tewkesbury et al. 2015). While remote sensing is sufficient in mapping land cover, for mapping land use, especially its intensity and the changes in its intensity a combination of remote sensing and other methods is needed (Erb et al. 2013; Kuemmerle et al. 2013; Meyfroidt et al. 2013; Temme and Verburg 2011). Thus, in order to understand the changes related to land use and link them to social processes, using remote sensing only is not sufficient. For instance, when grasping the multifaceted and contextual interactions between changes related to land, water and associated risks mixed methods are needed (Alemayehu et al. 2009; Desta et al. 2017; Forrester et al. 2015; Mapedza et al. 2003; Palmer et al. 2011; Qasim et al. 2013; Xue et al. 2015). Here, we combine remote sensing based LULC change analysis with qualitative evaluation of stakeholder perceptions of environmental change. The analysis of the institutional perceptions of the linkages between water, land and risks enabled us to grasp the governance context and the institutional views and values, which form a basis for policy decisions (Forrester et al. 2015; Suckall et al. 2014). 


\section{Study areas}

The case-study areas included in the study were: the River Vantaa basin in southern Finland, a section of the River Grijalva basin in Tabasco, southeastern Mexico, and the Lower Xe Bang Fai basin in southcentral Lao PDR (Fig. 2). We chose study areas which have different socio-cultural, political-economic and environmental contexts, and the combination of three divergent areas thus allows the analysis of how the land-water nexus and associated risks differentiate across three continents in developing, middleincome and developed countries. The study areas have complex land use histories and water-governance policies but they are also exposed to flood risks and to inadequate or deteriorating conditions of water quality, and several strategies have been recently implemented to mitigate these water-related risks. This offers us a good basis to analyze the institutional perceptions of the nexus between land use changes and water-related risks. Instead of a strictly comparative analysis, our purpose is to show the similarities and differences between the drivers of land use changes and their linkages to water-related risks across the cases. A description of the case study areas is given in Supplementary material 1, and the context of water governance in the cases is explained in Räsänen et al. (2017). 


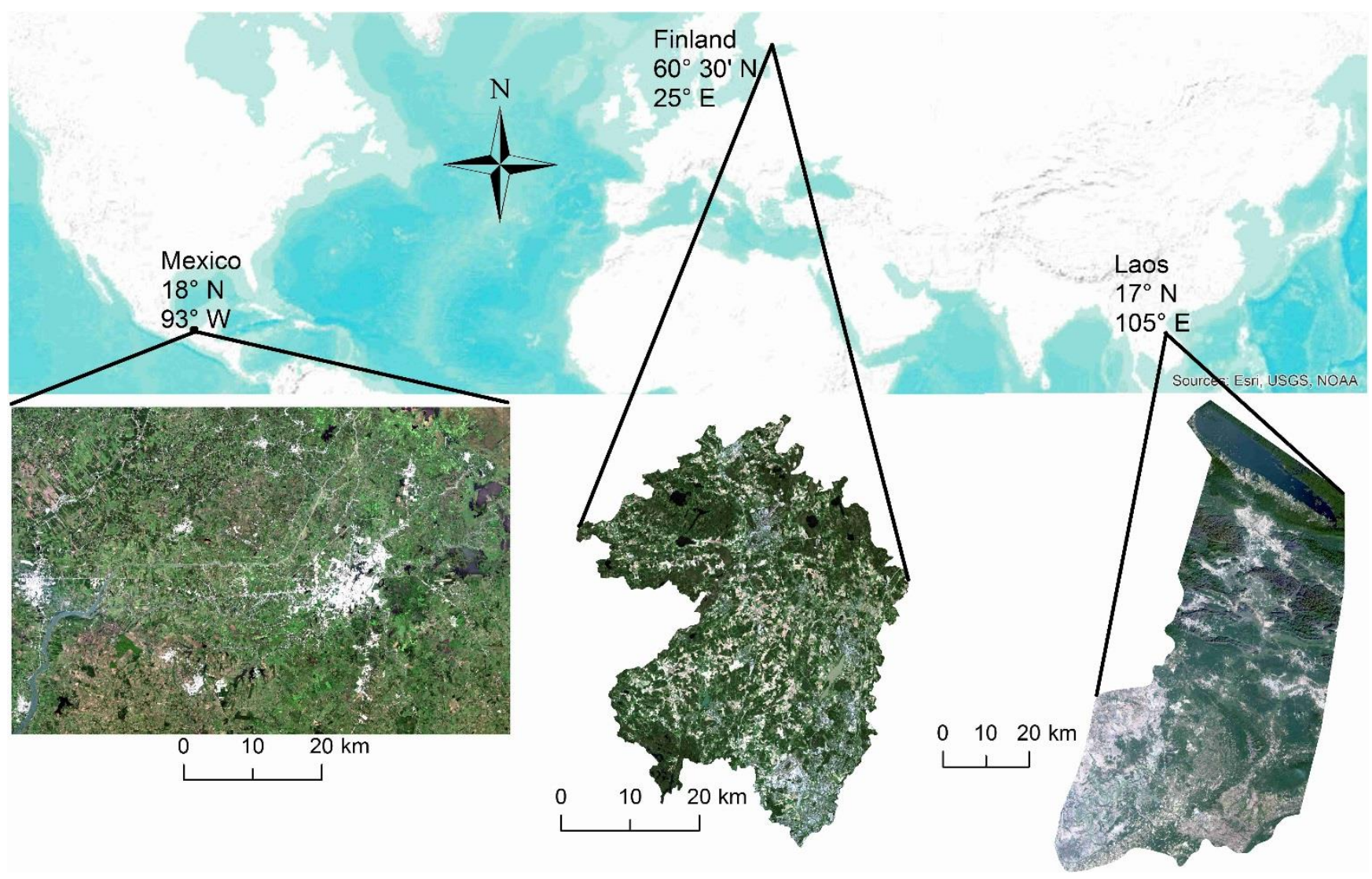

Figure 2. Case-study areas. USGS/NASA Landsat 8 satellite image from each site.

\section{Methods}

\section{Land use/land cover change analysis}

We quantified past changes in LULC using 30m spatial resolution Landsat images (A more detailed description of the classification approach is given in Supplementary material 2). For each site, we choose three images from different time points (Table 1). The analyzed images were taken approximately during the same time of the year to allow comparison across years. The images were first mosaicked and clipped and after that an object-based classification with Full Lambda Schedule image segmentation in ERDAS Imagine 2014 (Intergraph, Huntsville, AL, USA) and supervised random uniform forest (RUF) classification (Ciss 2015) in R 3.0.2 (R Core Team 2013) was performed. From each image, all color and 
infrared bands (bands $1-5$ and 7 in TM and ETM+ and bands $1-7$ in OLI) were used. In each study area, we classified images to 4-5 LULC classes. We assessed the accuracy of different classifications by evaluating RUF out-of-bag error rates and cross-compared the two newest Vantaa classifications to Finnish Corine Land Cover classifications from years 2000 (Finnish Environment Institute 2005) and 2012 (Härmä et al. 2013).

Table 1. Details of the Landsat images acquired from each study site.

\begin{tabular}{|c|c|c|c|}
\hline Study area & Date & Sensor & Path/Row \\
\hline Vantaa & 13.5.1985 & Landsat $5 \mathrm{TM}$ & $\begin{array}{l}189 / 17 \\
189 / 18\end{array}$ \\
\hline Vantaa & 29.5.2002 & Landsat 7 ETM+ & $188 / 18$ \\
\hline Vantaa & 25.5 .2015 & Landsat 8 OLI & $188 / 18$ \\
\hline Grijalva & 11.3.1986 & Landsat 5 TM & $\begin{array}{l}22 / 47 \\
22 / 48\end{array}$ \\
\hline Grijalva & 28.3.2001 & Landsat 7 ETM+ & $\begin{array}{l}22 / 47 \\
22 / 48\end{array}$ \\
\hline Grijalva & 8.3.2014 & Landsat 8 OLI & $\begin{array}{l}22 / 47 \\
22 / 48\end{array}$ \\
\hline Xe Bang Fai & 27.12.1987 & Landsat $5 \mathrm{TM}$ & $127 / 48$ \\
\hline Xe Bang Fai & 12.12.2002 & Landsat 7 ETM+ & $127 / 48$ \\
\hline Xe Bang Fai & 6.1 .2015 & Landsat 8 OLI & $127 / 48$ \\
\hline
\end{tabular}

\section{Stakeholder scenario workshops, documentary analysis and field visits}

Approaches, which involve stakeholder participants, have been considered useful in assessing different perceptions of environmental change (Fazey et al. 2011), including plans how to prepare for future changes (Frazier et al. 2010; Mitchell et al. 2016) and predict land use changes (Carpenter et al. 2015; 
Hewitt et al. 2014). Furthermore, stakeholder scenario workshops can be a forum for different opinions of land use and water-related changes (Frazier et al. 2010; Priess and Hauck 2014), and help to understand the underpinnings of local context (Smucker et al. 2007). The workshops, based on a methodology developed by Ravikumar et al. (2014), were organized on 2 September 2015 in Vantaa, Finland; on 2223 September 2015 in Villahermosa, Mexico; and on 22-23 October 2015 in Thakhek, Laos. We invited participants from different levels of public administration (central, regional, and municipal governments), private sector, and civil-society organizations (CSO) and research institutions. There were 20 participants in the workshop in Finland, 15-25 (depending on the session) in Mexico, and 32 in Laos. In the workshop, participants discussed what kind of water-related changes have happened in the study area during the past 30 years and identified key drivers influencing those changes. They also sketched potential future drivers of water-related changes and outlined how water-related risks and vulnerability could be reduced in the following 30 years. We analyzed (1) if land use or water governance changes were seen as key events or trends in relation to water-related risks and vulnerability, and (2) what kind of possible future changes related to land and water use were raised in the discussions and how the participants linked these changes to water-related risks and vulnerability.

To complement the workshop data, we also analyzed policy documents (Supplementary material 3) relevant for water governance in each study area to expand the situational knowledge gained through stakeholder scenario workshops (Smucker et al. 2007). From the documents, we evaluated (1) what kind of changes in land use have been documented in the study areas, (2) what kind of strategies for future changes are planned, and (3) how the relationships between land and water use changes and water-related risks and vulnerability have been formulated. In the case of Grijalva, and Xe Bang Fai, the materials were complemented with field visits and interviews with local residents and institutional stakeholders. 
In Grijalva, several months of fieldwork was carried out between 2011 and 2016; in Xe Bang Fai, empirical fieldwork was conducted in different parts of the basin during June-July 2016.

\section{Results}

\section{Quantifying past land use/land cover changes}

Overall, the classification accuracies were high with almost all out-of-bag accuracies being over $90 \%$ (Tables 2 to 4). In Vantaa, the similarities with Corine Land Cover classification were $78.8 \%$ and $81.5 \%$ respectively for years 2002 and 2015. The LULC changes have been most evident in Xe Bang Fai, although there have been notable changes in the other study areas.

In Vantaa, there has been a moderate increase in built-up housing and industrial areas over the past 30 years (Table 2). These areas have expanded both towards forest and agricultural areas (Fig. 3).

Table 2. The proportion of different Land use/land cover types and overall classification accuracies based on RUF out-of-bag estimates in Vantaa study area at three time-points.

\begin{tabular}{llllll}
\hline Year & Built-up & Agriculture & Forest & Water & Classification accuracy \\
\hline 1985 & $14.0 \%$ & $23.8 \%$ & $59.7 \%$ & $2.5 \%$ & $93.0 \%$ \\
2002 & $15.6 \%$ & $23.3 \%$ & $58.9 \%$ & $2.2 \%$ & $92.0 \%$ \\
2015 & $15.7 \%$ & $23.3 \%$ & $58.7 \%$ & $2.3 \%$ & $94.4 \%$ \\
\hline
\end{tabular}




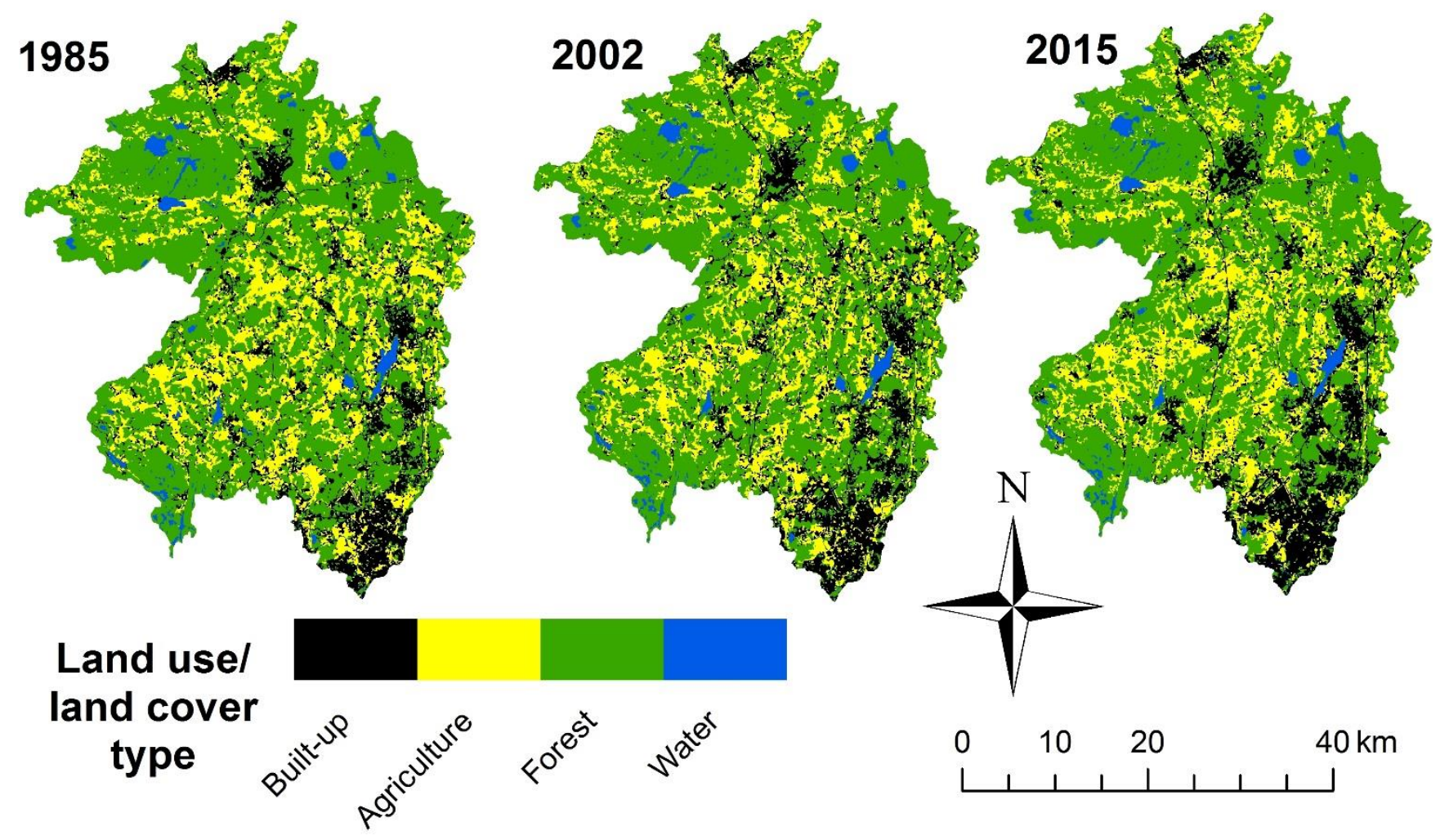

Figure 3. Land use/land cover maps of the Vantaa study area from years 1985, 2002 and 2015.

In Grijalva, there has been an increase both in built-up areas and tree plantations and a decrease in natural wetland vegetation cover and agricultural areas. The area covered by open water has fluctuated, which is probably caused in this delta area by precipitation patterns (Table 3). Most evident changes are the urban expansions around the cities of Villahermosa and Cardenas, located in the eastern and western parts of the study area respectively, and the decrease in natural wetland vegetation cover in the northeastern part (Fig. 4). This decrease in natural wetland vegetation is partly linked to the filling of several lagoons for construction purposes in areas close to Villahermosa, as well as to the conversion of wetland vegetation to pasturelands. 
Table 3. The proportion of different land use/land cover types and overall classification accuracies based on RUF out-of-bag estimates in Grijalva study area at three time-points.

\begin{tabular}{ccccccc}
\hline Year & Built-up & $\begin{array}{c}\text { Forests, tree } \\
\text { plant. and }\end{array}$ & $\begin{array}{c}\text { Agriculture } \\
\text { and }\end{array}$ & $\begin{array}{c}\text { Natural } \\
\text { wetland }\end{array}$ & Open water & Classification \\
& & agroforestry & pastureland & & & \\
\hline 1986 & $4.7 \%$ & $13.6 \%$ & $68.3 \%$ & $9.8 \%$ & $3.7 \%$ & $90.5 \%$ \\
2001 & $4.7 \%$ & $13.9 \%$ & $67.9 \%$ & $9.0 \%$ & $4.5 \%$ & $93.1 \%$ \\
2014 & $6.3 \%$ & $14.6 \%$ & $67.4 \%$ & $7.8 \%$ & $3.8 \%$ & $89.6 \%$ \\
\hline
\end{tabular}

1986

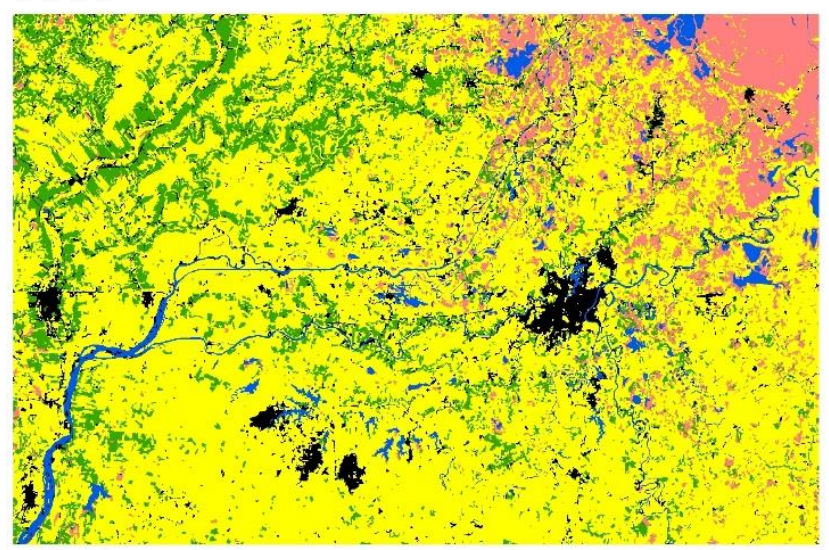

\section{4}

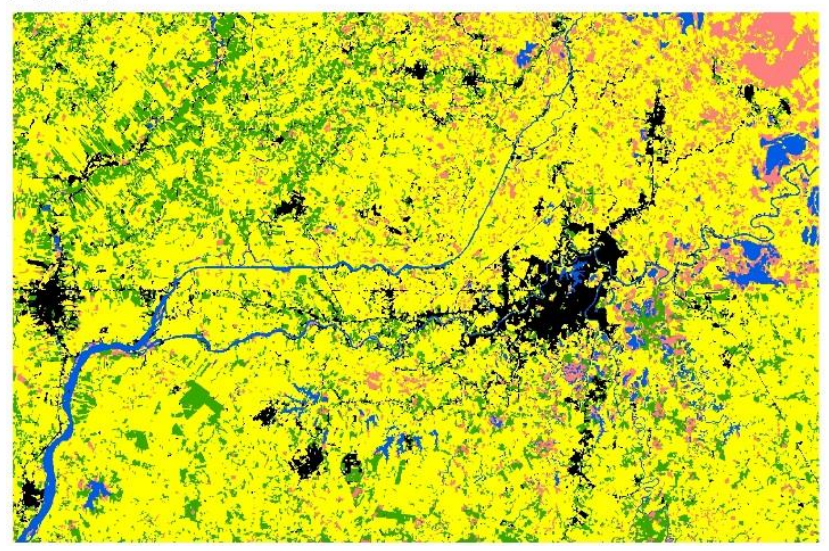

\section{1}

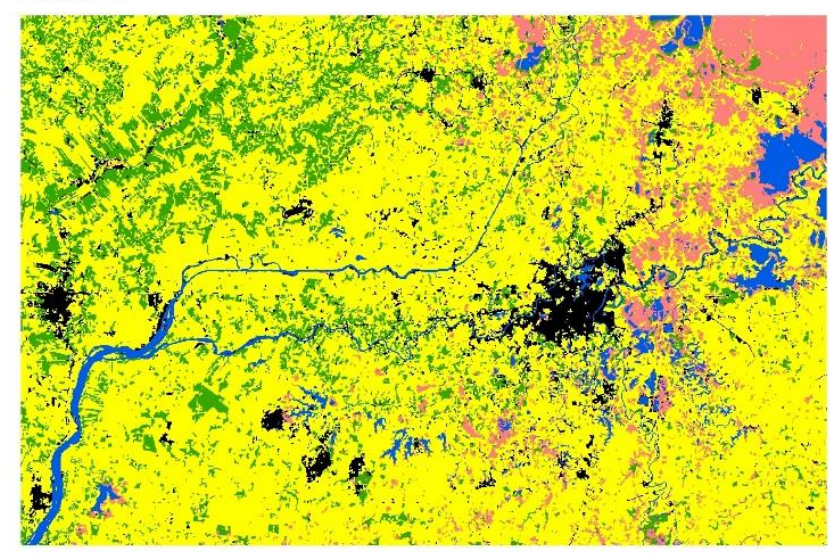

\section{Land use/land cover type}

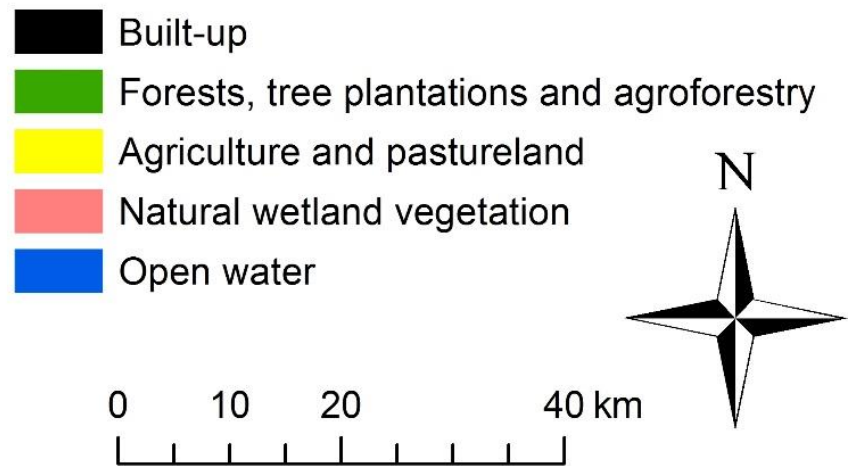

Figure 4. Land use/land cover maps of the Grijalva study area from years 1986, 2001, and 2014 
In Xe Bang Fai, there has been some expansion of built-up areas, which includes mining concessions, and of agricultural areas. However, the biggest changes have occurred in the decrease in forest cover and the increase of water areas (Table 4, Fig. 5). The increase in water areas relates to the construction of Nam Theun 2 dam, as the filling of the reservoir has produced a decrease in forest areas in particular and wetlands (classified as forests), which make up a small area in the study. Furthermore, the way these changes affect the flood-patterns downstream is determined by the way the dams are regulated. A significant proportion of the land-use changes has concentrated on the fertile, flood-prone areas downstream Xe Bang Fai. According to visual interpretation of very high resolution images and to information gathered during field visits, most of the increase in agricultural areas before 2002 was caused by rice paddy expansion. However, after 2002, a major part of the agricultural expansion consists of sugarcane plantations.

Table 4. The proportion of different land use/land cover types and overall classification accuracies based on RUF out-of-bag estimates in Xe Bang Fai study area.

\begin{tabular}{lrrrrrr}
\hline Year & Built-up & Agriculture & Forest & Barren & Water & Classification accuracy \\
\hline 1987 & $1.1 \%$ & $11.4 \%$ & $80.4 \%$ & $6.5 \%$ & $0.7 \%$ & $93.8 \%$ \\
2002 & $2.4 \%$ & $13.4 \%$ & $76.9 \%$ & $6.6 \%$ & $0.7 \%$ & $92.2 \%$ \\
2015 & $3.4 \%$ & $14.0 \%$ & $70.6 \%$ & $6.2 \%$ & $6.1 \%$ & $93.7 \%$ \\
\hline
\end{tabular}




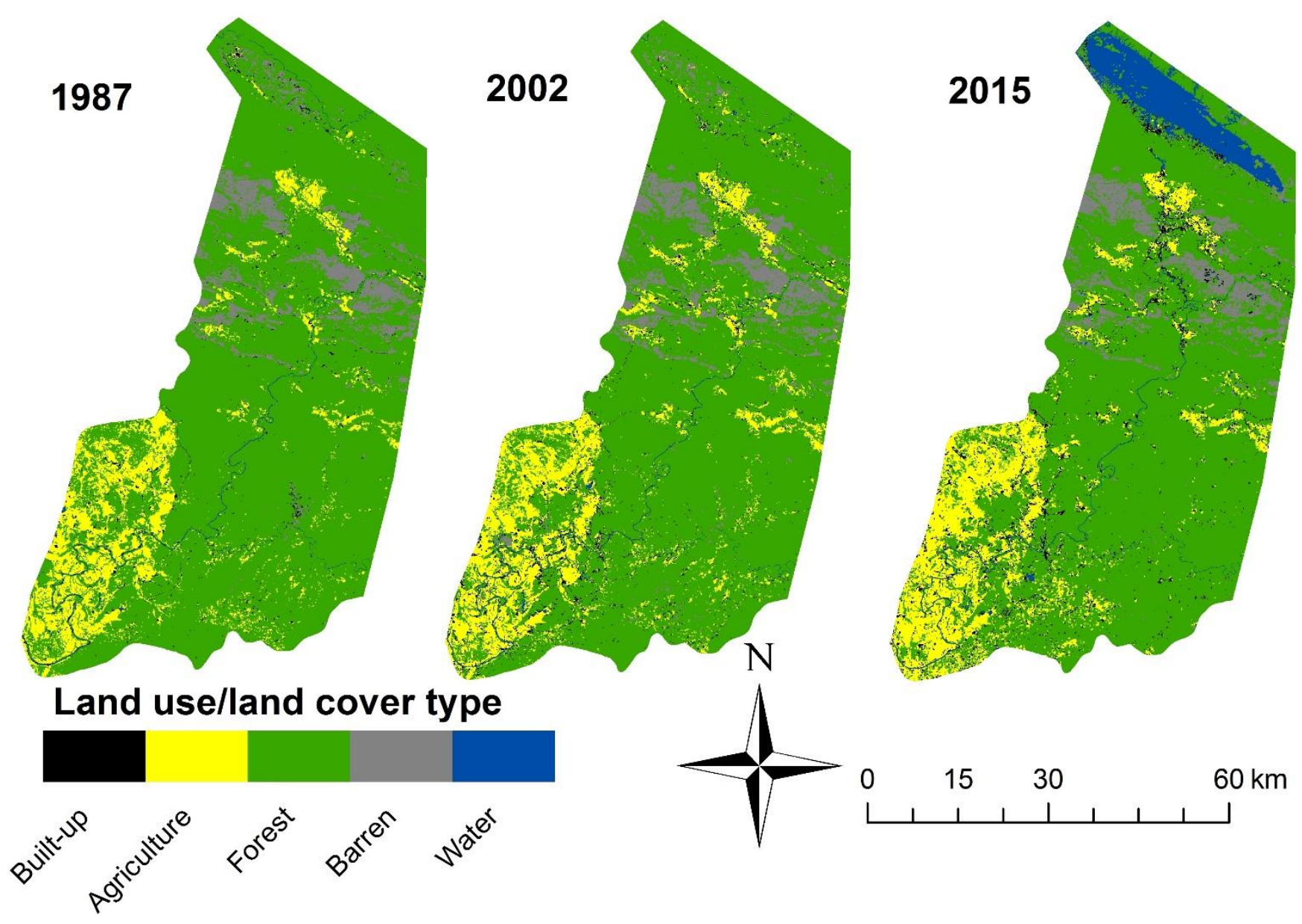

Figure 5. Land use/land cover maps of the Xe Bang Fai study area from years 1987, 2002 and 2015.

\section{Land use changes and water-related risks in the past}

In the historical timeline session of the Vantaa workshop, participants emphasized how changes in land use in the form of construction of new urban and sealed surface areas shorten the run-off times and possibly worsen the water quality and flood situation. Most changes were driven by population movement, mostly caused by migration from rural to urban areas and economic growth. There were also some remarks about the changes in agriculture, especially concerning the decreasing amounts of fertilizers used and the problems related to denser soils. The policy documents emphasized that Vantaa is situated along the most densely populated areas in Finland, with rapid urban expansion. According to the documents, intensification of agricultural and forestry practices has also decreased water quality and 
increased flood risks. The documents noted that there have been some nutrient pollution prevention measures in agriculture that have had positive effects to water quality, while at the same time remarking that the implementation of these has been slow.

In Grijalva, the most important past land and water use related events and trends mentioned in the workshop were the construction of dams in upstream areas of Grijalva River, the oil boom in 1980s, which included road constructions and human-promoted changes in river courses with impacts on flooding patterns, and oil-industry installations with impacts on water quality. Overall, the workshop discussions indicated that there have been changes in land and water use patterns in the area, with particular effects on water-related risks, especially concerning the residents' exposure to flood hazards and the deteriorating water quality. Policy documents made references to large hydrological modifications on the lowlands, including redirection and unification of major rivers and water bodies implemented more than a century ago. The latest policy documents also referred to various floodprevention programs that have been partially implemented during the last six decades to control serious flood events. Interviews with government officials, flood-governance consultants and NGO representatives revealed that the recent intensification of agriculture and cattle raising has had considerable effect on the sedimentation of the rivers; however, the main reasons for the magnitude of recent floods seem to be the inadequate operation of dams and expansion of urban settlement for areas not apt for dense settlement.

In Xe Bang Fai, one of the main land and water use change mentioned in the workshop was the Nam Theun 2 dam that has implied considerable changes in local livelihoods. The dam is built on the Nam Theun River but water from the reservoir is released to Xe Bang Fai, nearly doubling the mean flow of Xe Bang Fai (Descloux et al. 2014). In terms of historical events, people paid considerable attention to damaging floods. In terms of water-related land use changes, the main concerns were related to land use 
intensification using agrochemicals, increased logging and agribusiness and tree-plantation concessions, including sugar-cane and eucalyptus plantations, driven by large companies, and increase of mining concessions, including cement and potassium mines.

\section{Future land use changes and their linkages to water-related risks}

In Vantaa, the intensification of land use causes problems in controlling the water flows and may thus increase flooding and deteriorate water quality. However, at the same time, land use is regulated by flood management planning. Both the workshop discussions and analyzed policy documents indicated that the measures related to the intensification of agriculture affects water quality. It was recommended that new management practices in agriculture would be implemented to improve water quality, while allowing for an intensification of production. Participants in the workshop agreed that the problem of water quality is more severe than the issue of water quantity in the Vantaa area, and to control water quality, changes in agricultural practices are needed. However, some suggested that the flood problems could be mitigated by non-structural measures such as by restoring some of the lakes and wetlands that have been filled in the past. Flood mitigation is also connected with water quality, as that would result in less flood-related leakages from water-treatment facilities.

In the Grijalva basin, inadequate urban planning and construction on wetlands were seen as trends that will continue to increase the flood risks and catastrophic floods in the future. The participants considered that the amount of urban population will continue to grow but with adequate land use and urban-planning policies it would be possible to reduce the residents' exposure and vulnerability to floods. In addition to urban expansion, the development of oil-industrial infrastructure was mentioned as an important factor affecting land use and water quality changes. Reforestation strategies and the expansion of the transport infrastructure were also mentioned as potential drivers of future changes. Policy documents relied heavily on improved flood-protection infrastructure, as well as on the modifications in the hydrological networks 
on the lowlands to reduce flooding. Land use changes and urban planning were also mentioned as some of the crucial factors. However, their implementation was considered differently by governmental institutions, which prepared the documents.

In Xe Bang Fai, land use changes are occurring at a fast pace and it is probable that these changes will continue in the future. In the workshop discussions and in the policy documents, the role of foreign investments was identified as a significant driver for future land use change with important water-related implications. The participants recognized that land use changes affect both water quality and quantity; for instance, mining was considered to have negative effects on water quality, and loss of forest and wetland cover was expected to intensify both floods and droughts.

\section{Discussion}

Using multiple methods, our analysis shows that land use changes are one of the many factors relevant in terms of water-related changes and that an analysis of the rate of changes is not enough to understand the complexities between land use and water-related changes. Remote sensing analysis shows the general LULC changes and the potential locations for increased flood risks or decreased livelihood opportunities. Qualitative stakeholder scenario workshop discussions, policy-document analysis and field visits help to understand the changes in land use and its intensity, their drivers, linkages with water-related risks and projections to future changes in a much more thorough way.

Our three cases also enable us to consider the land use transformations and their implications on waterrelated risks. In each case, land use has had considerable impacts on water but at the same time, water use and governance has influenced land use patterns. In Vantaa, land use changes and management of agricultural land have increased pressures on water quality but these changes are also about water governance as intensification of land use has shortened run-off times. In Grijalva, widespread changes 
in water use and governance, including dam construction, water canalization and dyke construction have together with land use changes, transformed the whole river basin area. In Xe Bang Fai, there has been a rapid land use transformation but at the same time changes in water use in the form of a new dam has increased pressure to make changes in land use, such as changes from wet to dry season agriculture. In all study areas, the nexus between land, water and risks is recognized, and there have been shifts toward integration between policies especially in Vantaa and Grijalva. Nevertheless, there is a need for tighter integration, the situation which is similar to other basin areas across the globe (Benson and Lorenzoni 2017; Desta et al. 2017; Xue et al. 2015). Next, we will discuss the nexus in each study area more in detail.

In the case of Vantaa, the main changes in land use during the past 30 years were related to the increase of residential, industrial and urban areas. These changes were considered to increase water-related risks and to deteriorate water quality to a certain degree. Despite these changes, there is still almost $60 \%$ cover of near-natural forest vegetation. In other basins, with roughly similar land use patterns, models have shown that even small changes in land use or in climatic conditions can change the water regime significantly (Singh et al. 2014). This is especially relevant in the Vantaa basin, where the changes in runoff are naturally large, due to the low number of lakes and the small size of the basin (Suhonen and Rantakokko 2006; Suomalainen et al. 2015).

In the future, corresponding land use changes will probably continue in the Vantaa area; however, there are governmental plans to better integrate the policies of land use planning with those of water governance. First, it is unlikely that those zones that are flood-prone, will be built in the near future, and there are efforts to use more natural urban-runoff planning (Suomalainen et al. 2015). Second, less intensive agricultural management practices are being introduced (Karonen et al. 2015). In terms of water quality, the situation resembles the situation in several other basins in post-industrial countries, in which 
water quality has not improved, despite the more efficient management plans (Gillon et al. 2015). This is partly due to the shifting drivers that were not accounted for when the water governance policies were planned (Gillon et al. 2015).

In the case of Grijalva in Mexico, there have been drastic changes in the river basin management and in the land use patterns in the past two centuries, and these policies of technological risk prevention have continued during the last 30 years (Díaz Perera 2014). The building of massive water infrastructure has transformed the river's runoff patterns and paradoxically increased people's exposure to flood risks; the situation similar to many other deltaic river basins and flood plains in the world (Marçal et al. 2017; Ritzema and Van Loon-Steensma 2017; Sze et al. 2009). The changes in river courses, sedimentation of the rivers due to agricultural activities - especially the cattle raising - and the high degree of social inequality have increased especially the poor inhabitants' exposure to serious flood hazards; affecting most the already highly vulnerable people (Nygren 2016; Sze et al. 2009). The coverage of natural forest and wetland vegetation was small already for 30 years ago; nevertheless, in the past 30 years, there has been a significant increase in built-up areas especially in the most critical risk zones, and this rate of change has been more drastic and faster in Grijalva than in Vantaa. The past 30 years have also seen a widespread human-induced modification of the landscape, including massive water canalization, water contamination and the expansion of human settlement and agricultural activities to natural floodretention areas.

For the future, the question is how the water governance and land use can be planned so that flood risks and vulnerabilities could be reduced. Although it is difficult to reverse the widespread infrastructural modifications implemented in the area, environmental governance should be shifted towards directions that are ecologically more sensitive and socially more transparent. These including policies that "give more space for the river" and that integrate sectors better and enable socially more inclusive forms of 
water governance and land use planning (Nygren 2016; Sze et al. 2009). These kinds of multi-sectoral and socially inclusive forms of governance are crucial to decrease the risks related to catastrophic floods and everyday vulnerability, including access to safe drinking water and reduction of sedimentation and water contamination.

In Xe Bang Fai, the expansion of agriculture and built-up areas has been fast in the past 30 years. In addition, the construction of the Nam Theun 2 dam has transformed a large land area in the Nakai Plateu into a reservoir from where water is channeled to the Xe Bang Fai river causing significant changes in its water-flow regime (Baird et al. 2015). Changes in the river's flow regime have prolonged floods and caused significant losses in wet season rice harvests, but also affected fisheries-based activities. Furthermore, changes in the flood regime create pressures to shift from wet to dry season agriculture, which is heavily promoted by the government officials and international donors, like the World Bank and Asian Development Bank. However, in a monsoon area, such as Xe Bang Fai, the irrigated dry season cultivation implies high water pumping, fertilization and labor input costs (Floch and Molle 2013; Hoanh et al. 2012). Importantly, all the residents are not likely to be able to take advantage of this shift; in fact, some of them may end up indebted and worse off, which increases rural inequalities, as well as differentiated capabilities to cope with exceptionally strong floods. In turn, the new mining concessions have major implications on water-related problems, especially the potassium mines, which worsen the water quality in certain areas, affecting both fisheries and rice harvests. This seems to contradict with the government policy to have Xe Bang Fai Basin as one of the country's priority areas for rice production. The plantation and agribusiness concessions may increase local inhabitants' vulnerability to floods by diminishing the livelihoods options due to restricted possibilities for upland activities, including the collection of non-timber forest products (Friis et al. 2016; Lagerqvist et al. 2014; Thulstrup 2014). 
In the future, the cumulative impacts of the different extractive and agro-industrial projects (Baird and Barney 2017), inconsistent policies and policy implementations are a key in making people vulnerable to devastating floods that are likely to become more frequent due to climate change. The question is how to govern future changes in a way that people's exposure to floods and other water-related changes can be mitigated, and the resilience of the local livelihoods strengthened. There is a need for more integrated land use planning and for water governance decisions that are more sensitive to the mosaic of local livelihoods. This implies addressing carefully the cumulative impacts of dam, mining and agribusiness concessions that constrain the ways people combine the use of the lowland paddies with the use of riverine and up-land forest resources.

\section{Conclusion}

We quantified LULC changes of past 30 years, projected future changes and analyzed how the relationships between land use changes and water-related risks and vulnerability were perceived by institutional stakeholders in three study areas, located in Finland, Mexico and Laos. Although land use changes and their drivers exert pressures on water governance, our analysis demonstrated that a simple mapping of LULC patterns and rates of change is not sufficient, thus both remote sensing and qualitative data analysis are needed.

Our analysis showed that water-related risks are produced through interconnected land use and water governance changes, as well as through a complex mixture of overlapping, interacting and competing processes and policies. Our approach enabled us to analyze the land-water-nexus in different sociocultural and political-economic contexts. We found that there was an evident nexus between land and water in each study area, but the actual interlinkages between land and water were divergent in different contexts. We also found that the institutional stakeholders recognized the nexus in each study area but there have been few integrated policies that would holistically account for water-related risks. The past 
land use and water related changes and the probable future transformations exert considerable pressures on the governance of water quality and quantity in all the three study areas. Our analysis further emphasizes calls to move from a water-land divide into a nexus-oriented thinking that considers the changes in both land use and water governance, and their context-specific interconnections, when planning the future policies and seeking for more sustainable way to reduce the water-related risks and vulnerability.

\section{Acknowledgements}

The research was funded by Helsinki University Centre for Environment (HENVI), project number 77255106.

\section{References}

Alemayehu F et al. (2009) The impacts of watershed management on land use and land cover dynamics in Eastern Tigray (Ethiopia) Resources, Conservation and Recycling 53:192-198 doi:10.1016/j.resconrec.2008.11.007

Alexakis D et al. (2014) GIS and remote sensing techniques for the assessment of land use change impact on flood hydrology: the case study of Yialias basin in Cyprus Natural Hazards and Earth System Science 14:413-426

Baird IG, Barney K (2017) The political ecology of cross-sectoral cumulative impacts: modern landscapes, large hydropower dams and industrial tree plantations in Laos and Cambodia Journal of Peasant Studies 44:884-910 doi:10.1080/03066150.2017.1289921

Baird IG, Shoemaker BP, Manorom K (2015) The People and their River, the World Bank and its Dam: Revisiting the Xe Bang Fai River in Laos Development and Change 46:1080-1105 
Benson D, Lorenzoni I (2017) Climate change adaptation, flood risks and policy coherence in integrated water resources management in England Regional Environmental Change 17:19211932 doi:10.1007/s10113-016-0959-6

Borchardt D, Bogardi JJ, Ibisch RB (2016) Integrated Water Resources Management: Concept, Research and Implementation. Springer, Cham. doi:10.1007/978-3-319-25071-7

Carpenter SR et al. (2015) Plausible futures of a social-ecological system: Yahara watershed, Wisconsin, USA Ecology and Society 20:10

Chen B et al. (2018) Global land-water nexus: Agricultural land and freshwater use embodied in worldwide supply chains Science of the Total Environment 613-614:931-943 doi:10.1016/j.scitotenv.2017.09.138

Ciss S (2015) randomUniformForest: random Uniform Forests for Classification, Regression and Unsupervised Learning. R package version 1.1.5. http://CRAN.Rproject.org/package=randomUniformForest. Accessed 9.2. 2016

de Moel H, Aerts JC, Koomen E (2011) Development of flood exposure in the Netherlands during the 20th and 21st century Global Environmental Change 21:620-627

Delpla I, Jung AV, Baures E, Clement M, Thomas O (2009) Impacts of climate change on surface water quality in relation to drinking water production Environment International 35:1225-1233 doi:10.1016/j.envint.2009.07.001

Descloux S, Guedant P, Phommachanh D, Luthi R (2014) Main features of the Nam Theun 2 hydroelectric project (Lao PDR) and the associated environmental monitoring programmes Hydroécologie Appliquée

Desta H, Lemma B, Gebremariam E (2017) Identifying sustainability challenges on land and water uses: The case of Lake Ziway watershed, Ethiopia Applied Geography 88:130-143 doi:10.1016/j.apgeog.2017.09.005 
Díaz Perera MÁ (2014) La construcción histórica de las condiciones de posibilidad de un desastreel caso de dos colonias de Villahermosa, Tabasco. In: González-Espinosa M, Brunel Manse MC (eds) Montañas, pueblos y agua: Dimensiones y realidades de a Cuenca Grijalva. El Colegio de la Frontera Sur, San Cristóbal de Las Casas, pp 181-212

Erb K-H et al. (2013) A conceptual framework for analysing and measuring land-use intensity Current opinion in environmental sustainability 5:464-470

Fazey I, Pettorelli N, Kenter J, Wagatora D, Schuett D (2011) Maladaptive trajectories of change in Makira, Solomon Islands Global Environmental Change-Human and Policy Dimensions 21:1275-1289 doi:10.1016/j.gloenvcha.2011.07.006

Finnish Environment Institute (2005) CLC2000-Finland: Final Report. Finnish Environment Institute, Floch P, Molle F (2013) Irrigated agriculture and rural change in northeastern Thailand: reflections on present developments. In: Daniel R, Lebel L, Manorom K (eds) Governing the Mekong: engaging in the politics of knowledge. Strategic Information and Research Development Center (SIRD), Petaling Jaya, Malaysia, pp 185-198

Foley JA et al. (2005) Global consequences of land use science 309:570-574

Forrester J, Cook B, Bracken L, Cinderby S, Donaldson A (2015) Combining participatory mapping with Q-methodology to map stakeholder perceptions of complex environmental problems Applied Geography 56:199-208 doi:10.1016/j.apgeog.2014.11.019

Frazier TG, Wood N, Yarnal B (2010) Stakeholder perspectives on land-use strategies for adapting to climate-change-enhanced coastal hazards: Sarasota, Florida Applied Geography 30:506-517

Friis C, Reenberg A, Heinimann A, Schönweger O (2016) Changing local land systems: Implications of a Chinese rubber plantation in Nambak District, Lao PDR Singapore Journal of Tropical Geography 37:25-42 doi:10.1111/sjtg.12137 
Gao B, Yang D, Yang H (2013) Impact of the Three Gorges Dam on flow regime in the middle and lower Yangtze River Quaternary International 304:43-50 doi:10.1016/j.quaint.2012.11.023

Gillon S, Booth EG, Rissman AR (2015) Shifting drivers and static baselines in environmental governance: challenges for improving and proving water quality outcomes Regional Environmental Change:1-17

Güneralp B, Güneralp İ, Liu Y (2015) Changing global patterns of urban exposure to flood and drought hazards Global Environmental Change 31:217-225

Hewitt R, Van Delden H, Escobar F (2014) Participatory land use modelling, pathways to an integrated approach Environmental Modelling \& Software 52:149-165

Hoanh CT, Facon T, Thuon T, Bastakoti RC, Molle F, Phengphaengsy F (2012) Irrigation in the lower mekong basin countries: The beginning of a new era? In: Contested Waterscapes in the Mekong Region: Hydropower, Livelihoods and Governance. pp 143-172. doi:10.4324/9781849770866

Härmä P et al. (2013) GIO land monitoring 2011 - 2013 in the framework of regulation (EU) No 911/2010. Final report. Finland. Finnish Environment Institute,

IPCC (2014) Summary for policymakers. In: Field CB, V.R. Barros, D.J. Dokken, K.J. Mach, M.D. Mastrandrea, T.E. Bilir, M. Chatterjee, K.L. Ebi, Y.O. Estrada, R.C. Genova, B. Girma, E.S. Kissel, A.N. Levy, S. MacCracken, P.R. Mastrandrea, and L.L. White (ed) Climate Change 2014: Impacts, Adaptation, and Vulnerability. Part A: Global and Sectoral Aspects.

Contribution of Working Group II to the Fifth Assessment Report of the Intergovernmental Panel on Climate Change. Cambridge University Press, Cambridge, United Kingdom and New York, NY, USA, pp 1-32

Karonen M, Mäntykoski A, Lankiniemi V, Nylander E, Lehto K (eds) (2015) Uudenmaan vesienhoidon toimenpideohjelma. 
Kuemmerle T et al. (2013) Challenges and opportunities in mapping land use intensity globally Current opinion in environmental sustainability 5:484-493

Lagerqvist YF, Woollacott L, Phasouysaingam A, Souliyavong S (2014) Resource Development and the Perpetuation of Poverty in Rural Laos Australian Geographer 45:407-417 doi:10.1080/00049182.2014.930006

Lambin EF et al. (2001) The causes of land-use and land-cover change: moving beyond the myths Global environmental change 11:261-269

Lioubimtseva E, Henebry GM (2009) Climate and environmental change in arid Central Asia: Impacts, vulnerability, and adaptations Journal of Arid Environments 73:963-977 doi:10.1016/j.jaridenv.2009.04.022

Liu J, Wang S-y, Li D-m (2014) The analysis of the impact of land-use changes on flood exposure of Wuhan in Yangtze River Basin, China Water resources management 28:2507-2522

Liu Y, Long H, Li T, Tu S (2015) Land use transitions and their effects on water environment in Huang-Huai-Hai Plain, China Land Use Policy 47:293-301

Lu XX, Li S, Kummu M, Padawangi R, Wang JJ (2014) Observed changes in the water flow at Chiang Saen in the lower Mekong: Impacts of Chinese dams? Quaternary International 336:145-157 doi:10.1016/j.quaint.2014.02.006

Mapedza E, Wright J, Fawcett R (2003) An investigation of land cover change in Mafungautsi Forest, Zimbabwe, using GIS and participatory mapping Applied Geography 23:1-21

Marçal M, Brierley G, Lima R (2017) Using geomorphic understanding of catchment-scale process relationships to support the management of river futures: Macaé Basin, Brazil Applied Geography 84:23-41 doi:10.1016/j.apgeog.2017.04.008 
McCubbin S, Smit B, Pearce T (2015) Where does climate fit? Vulnerability to climate change in the context of multiple stressors in Funafuti, Tuvalu Global Environmental Change-Human and Policy Dimensions 30:43-55 doi:10.1016/j.gloenvcha.2014.10.007

Meyfroidt P, Lambin EF, Erb K-H, Hertel TW (2013) Globalization of land use: distant drivers of land change and geographic displacement of land use Current Opinion in Environmental Sustainability 5:438-444

Mitchell M, Lockwood M, Moore SA, Clement S, Gilfedder L, Anderson G (2016) Using scenario planning to assess governance reforms for enhancing biodiversity outcomes Land Use Policy 50:559-572 doi:10.1016/j.landusepol.2015.10.020

Muñoz-Salinas E, Castillo M (2015) Streamflow and sediment load assessment from 1950 to 2006 in the Usumacinta and Grijalva rivers (Southern Mexico) and the influence of ENSO Catena 127:270-278 doi:10.1016/j.catena.2015.01.007

Nygren A (2016) Socially differentiated urban flood governance in Mexico: Ambiguous negotiations and fragmented contestations Journal of Latin American Studies 48:335-365

Pahl-Wostl C (2015) Water Governance in the Face of Global Change: From Understanding to Transformation. Springer, Heidelberg, Germany

Palmer BJ, Hill TR, Mcgregor GK, Paterson AW (2011) An assessment of coastal development and land use change using the DPSIR framework: Case studies from the Eastern Cape, South Africa Coastal Management 39:158-174

Priess JA, Hauck J (2014) Integrative scenario development Ecol Soc 19:12

Qasim M, Hubacek K, Termansen M (2013) Underlying and proximate driving causes of land use change in district Swat, Pakistan Land Use Policy 34:146-157

R Core Team (2013) R: A language and environment for statistical computing. R Foundation for Statistical Computing, Vienna, Austria 
Rahman K, da Silva AG, Tejeda EM, Gobiet A, Beniston M, Lehmann A (2015) An independent and combined effect analysis of land use and climate change in the upper Rhone River watershed, Switzerland Applied Geography 63:264-272 doi:10.1016/j.apgeog.2015.06.021

Ravikumar A, Gonzales J, Kowler L, Larson A (2014) Building future scenarios: Governance, land use and carbon management at the landscape scale. Workshop facilitation guide. Center for International Forestry Research (CIFOR), Bogor, Indonesia,

Ringler C, Bhaduri A, Lawford R (2013) The nexus across water, energy, land and food (WELF): Potential for improved resource use efficiency? Current Opinion in Environmental Sustainability 5:617-624 doi:10.1016/j.cosust.2013.11.002

Ritzema HP, Van Loon-Steensma JM (2017) Coping with Climate Change in A densely Populated Delta: A Paradigm Shift in Flood And Water Management in The Netherlands Irrigation and Drainage doi:10.1002/ird.2128

Rockström J et al. (2014) The unfolding water drama in the Anthropocene: towards a resilience-based perspective on water for global sustainability Ecohydrology 7:1249-1261

Rockström J et al. (2009) A safe operating space for humanity Nature 461:472-475

Räsänen A, Juhola S, Monge Monge A, Käkönen M, Kanninen M, Nygren A (2017) Identifying mismatches between institutional perceptions of water-related risk drivers and water management strategies in three river basin areas Journal of Hydrology 550:704-715 doi:10.1016/j.jhydrol.2017.05.040

Singh A (1989) Review article digital change detection techniques using remotely-sensed data International journal of remote sensing 10:989-1003

Singh R, Wagener T, Crane R, Mann M, Ning L (2014) A vulnerability driven approach to identify adverse climate and land use change combinations for critical hydrologic indicator thresholds: Application to a watershed in Pennsylvania, USA Water Resources Research 50:3409-3427 
Smucker TA, Campbell DJ, Olson JM, Wangui EE (2007) Contemporary challenges of participatory field research for land use change analyses: Examples from Kenya Field Methods 19:384-406 Steffen W et al. (2015) Planetary boundaries: Guiding human development on a changing planet Science 347:1259855

Suckall N, Tompkins E, Stringer L (2014) Identifying trade-offs between adaptation, mitigation and development in community responses to climate and socio-economic stresses: Evidence from Zanzibar, Tanzania Applied Geography 46:111-121 doi:10.1016/j.apgeog.2013.11.005

Suhonen V, Rantakokko K (2006) Vantaanjoen tulvantorjunnan toimintasuunnitelma. Uudenmaan ympäristökeskus, Helsinki

Suomalainen M, Seppälä R, Jaakonaho O (2015) Vantaanjoen vesistöalueen tulvariskien hallintasuunnitelma vuosille 2016-2021. Hämeen elinkeino-, liikenne ja ympäristökeskus,

Sze J, London J, Shilling F, Gambirazzio G, Filan T, Cadenasso M (2009) Defining and Contesting Environmental Justice: Socio-natures and the Politics of Scale in the Delta Antipode 41:807843

Temme A, Verburg P (2011) Mapping and modelling of changes in agricultural intensity in Europe Agriculture, Ecosystems \& Environment 140:46-56

Tewkesbury AP, Comber AJ, Tate NJ, Lamb A, Fisher PF (2015) A critical synthesis of remotely sensed optical image change detection techniques Remote Sensing of Environment 160:1-14 Thulstrup AW (2014) Plantation livelihoods in central Vietnam: Implications for household vulnerability and community resilience Norsk Geografisk Tidsskrift 68:1-9 doi:10.1080/00291951.2013.870928

Tong STY, Sun Y, Ranatunga T, He J, Yang YJ (2012) Predicting plausible impacts of sets of climate and land use change scenarios on water resources Applied Geography 32:477-489 doi:10.1016/j.apgeog.2011.06.014 
Tu J (2011) Spatially varying relationships between land use and water quality across an urbanization gradient explored by geographically weighted regression Applied Geography 31:376-392 doi:10.1016/j.apgeog.2010.08.001

Wang LJ, Wu L, Hou XY, Zheng BH, Li H, Norra S (2016) Role of reservoir construction in regional land use change in Pengxi River basin upstream of the Three Gorges Reservoir in China Environmental Earth Sciences 75 doi:10.1007/s12665-016-5758-3

Wilson CO (2015) Land use/land cover water quality nexus: quantifying anthropogenic influences on surface water quality Environmental monitoring and assessment 187:1-23

Xue X, Liao J, Hsing Y, Huang C, Liu F (2015) Policies, Land Use, and Water Resource Management in an Arid Oasis Ecosystem Environmental Management 55:1036-1051 doi:10.1007/s00267$015-0451-y$

Zhang L, Karthikeyan R, Bai Z, Srinivasan R (2017) Analysis of streamflow responses to climate variability and land use change in the Loess Plateau region of China Catena 154:1-11 doi:10.1016/j.catena.2017.02.012

Zhou F, Xu Y, Chen Y, Xu C-Y, Gao Y, Du J (2013) Hydrological response to urbanization at different spatio-temporal scales simulated by coupling of CLUE-S and the SWAT model in the Yangtze River Delta region Journal of Hydrology 485:113-125 